\title{
Pathogenic potential of Aeromonas hydrophila isolated from surface waters in Kolkata, India
}

Correspondence

Prasanta K. Bag

pkbbioc@caluniv.ac.in

Received 14 July 2009

Accepted 24 August 2009

\author{
Poulami Bhowmik, ${ }^{1}$ Prasanta K. Bag, ${ }^{1}$ Tapas K. Hajra, ${ }^{1}$ Rituparna De, ${ }^{2}$ \\ Pradipto Sarkar ${ }^{1}$ and T. Ramamurthy ${ }^{2}$
}

\author{
${ }^{1}$ Department of Biochemistry, University of Calcutta, 35 Ballygunge Circular Road, Kolkata 700 \\ 019, India \\ ${ }^{2}$ National Institute of Cholera and Enteric Diseases, P-33 C.I.T. Road, Scheme-XM, Beliaghata, \\ Kolkata 700 010, India
}

\begin{abstract}
Members of the genus Aeromonas (family Aeromonadaceae) are medically important, Gramnegative, rod-shaped micro-organisms and are ubiquitous in aquatic environments. Aeromonas species are increasingly recognized as enteric pathogens; they possess several virulence factors associated with human disease, and represent a serious public health concern. In the present study, putative virulence traits of Aeromonas hydrophila isolates collected from different natural surface waters of Kolkata, India, were compared with a group of clinical isolates from the same geographical area using tissue culture and PCR assays. Enteropathogenic potential was investigated in the mouse model. Of the 21 environmental isolates tested, the majority showed cytotoxicity to HeLa cells ( $81 \%)$, haemolysin production $(71 \%)$ and serum resistance properties (90\%), and they all exhibited multi-drug resistance. Some of the isolates induced fluid accumulation (FA ratio $\geqslant 100$ ), damage to the gut and an inflammatory reaction in the mouse intestine; these effects were comparable to those of clinical strains of $A$. hydrophila and toxigenic Vibrio cholerae. Interestingly, two of the isolates evoked a cell vacuolation effect in HeLa cells, and were also able to induce FA. These findings demonstrate the presence of potentially pathogenic and multi-drug-resistant $A$. hydrophila in the surface waters, thereby indicating a significant risk to public health. Continuous monitoring of surface waters is important to identify potential waterborne pathogens and to reduce the health risk caused by the genus Aeromonas.
\end{abstract}

\section{INTRODUCTION}

Aeromonas species are ubiquitous micro-organisms isolated from clinical, environmental and food samples (Agger et al., 1985; Hanninen \& Siitonen, 1995; Sinha et al., 2004). They have been documented in a variety of human illnesses, including septicaemia, meningitis, wound infections and lung infections (Janda \& Abbott, 1998), although the most frequent reports indicate the association of Aeromonas species with acute gastroenteritis. However, the aetiological role of Aeromonas species in bacterial gastroenteritis is not yet clearly understood. Aeromonads are heterogeneous and only certain subgroups may be pathogenic; hence, it is difficult to assign an unequivocal

Part of this work (Abstract) has been presented at the US-Japan Cooperative Medical Science Program (CMSP) 13th International Conference on Emerging Infectious Diseases in the Pacific Rim (Kolkata, India, 6-9 April 2009).

Abbreviation: FA, fluid accumulation.

Tables of PCR primers used in this study, and of correlation of variable biochemical characteristics with cytotoxin production and adherence for environmental isolates are available with the online version of this paper. role for these organisms in human diarrhoeal disease (Kühn et al., 1997). Among bacteria-mediated gastroenteritis, the genus Aeromonas is increasingly recognized as an enteric pathogen (Janda, 1991; Janda \& Abbott, 1998). Although a strong association between diarrhoeal disease and Aeromonas hydrophila has been shown in children and in adults $>60$ years old, this organism has been isolated from cases of travellers' diarrhoea with high frequency (Agger et al., 1985; Hanninen et al., 1995; Yamada et al., 1997). A recent study indicated that Aeromonas-associated diarrhoea is sporadic, similar to infections caused by Vibrio cholerae non-O1 and non-O139 serogroups (Sinha et al., 2004).

The pathogenesis of Aeromonas infection is complex and multifactorial (Janda \& Abbott, 1998; Chopra et al., 2000). Aeromonas species produce a variety of virulence factors, including cytotoxic and cytotonic enterotoxins, aerolysins, haemolysins, proteases, haemagglutinins and lipases (Merino et al., 1999), and are invasive to cultured cell lines (Lawson et al., 1985). A high isolation rate of aeromonads has been documented from the environment as well as from humans (Albert et al., 2000; Sinha et al., 
2004). Albert et al. (2000) reported that isolates of Aeromonas spp. harbour both alt and ast genes, encoding heat-labile cytotonic and heat-stable cytotonic enterotoxin, respectively, associated with watery diarrhoea. The isolation rate of Aeromonas species from diarrhoeic stool has been reported to be as high as $10.8 \%$, compared to only $2.1 \%$ from the stools of healthy control subjects (Edberg et al., 2007; Suarez et al., 2008). It has been reported that Aeromonas species, including A. hydrophila and Aeromonas sobria were the most frequently isolated $(22.6 \%$ of all isolates) bacteria from southern Thailand tsunami survivors (Hiransuthikul et al., 2005). These survivors were exposed to contaminated water after their area was flooded by the tsunami wave. Furthermore, high numbers of Aeromonas spp. were found in floodwater samples collected after hurricane Katrina in New Orleans (Presley et al., 2006). In many epidemiological investigations it has been shown clearly that there is a link between water sources and Aeromonas-mediated infections (Edberg et al., 2007). The increasing frequency of reports of aquatic-environmentassociated human infections, such as those caused by Aeromonas, makes it important to know whether the environmental isolates possess virulence-associated factors and therefore represent an increased health risk for humans (Krovacek et al., 1994). Hence, it is important to isolate and determine the frequency of occurrence of the aetiological agents of diarrhoea in the natural environment and to characterize them in detail. We report here the isolation of A. hydrophila from natural surface waters, and its ability to produce virulence-associated factors similar to that in clinical isolates. We also investigated the enteropathogenic potential of some of the isolates in animal models, and compared them with clinical strains of $A$. hydrophila and toxigenic $V$. cholerae.

\section{METHODS}

Study area and sample collection. Sixteen different sites (Canning, Budge Budge, Lakshmikantapur, Sonarpur, Jadavpur, Dum Dum, Kalighat, Rajarhat, Chetla, Mudialy, Taratala, Bally, Taldi, Behala, Dakshin Barasat and Deulti) located in Kolkata and its surroundings, West Bengal, India, were selected because diarrhoeal diseases are endemic in these areas (Bag et al., 2008). These water sources are used for domestic purposes, such as bathing, washing of clothes and utensils, and cooking, by the community and are probably linked to infections by enteropathogens. Water samples were collected in sterile $250 \mathrm{ml}$ glass bottles from ponds and canals $(5 \mathrm{~cm}$ below the water surface) bi-weekly from April 2001 to March 2003. Inoculations into selective media were conducted within $24 \mathrm{~h}$ after collection of the water samples.

Isolation and identification of bacteria. Ten millilitres of water sample was inoculated into $10 \mathrm{ml}$ double-strength alkaline peptonewater ( $\mathrm{pH}$ 8.6) and incubated at $37{ }^{\circ} \mathrm{C}$ for $24 \mathrm{~h}$. A sample from this enrichment culture was streaked with a loop on thiosulfate-citratebile salts-sucrose (TCBS) agar (Eiken) and incubated for $24 \mathrm{~h}$ at $37{ }^{\circ} \mathrm{C}$ (Kühn et al., 1997). Yellow or green colonies were picked from the TCBS agar (Kühn et al., 1997). These colonies were first examined by a single-tube multi-test medium (Kaper et al., 1979). Strains exhibiting an alkaline slant/acid butt reaction were further tested for cytochrome $c$ oxidase activity by Kovacs method (Cowan, 1979). Oxidase-positive isolates were also tested for the string reaction (Smith, 1970) and sensitivity to the vibriostatic agent 2,2-diamine6,7-diisopropylpteridine phosphate $(\mathrm{O} / 129)$ with $150 \mu \mathrm{g}$ disks. A. hydrophila generally gives a negative string test (Smith, 1970) and is resistant to the vibriostatic agent $\mathrm{O} / 129(150 \mu \mathrm{g})$. Oxidase-positive strains were identified by the methods outlined in Cowan (1979), West \& Colwell (1984), Holt et al. (1994) and Abbott et al. (2003) by using conventional biochemical tests (Ewing \& Davis, 1981; Collee et al., 1996). Salt tolerance was determined by growth of the isolates at $37{ }^{\circ} \mathrm{C}$ in $1 \%$ peptone broth without $\mathrm{NaCl}$ or supplemented with $7 \%$ $\mathrm{NaCl}$. Shape and motility were determined by phase-contrast microscopy (model BX51/B52; Olympus). For comparison, standard strains of A. hydrophila (AN1 and MTCC 646) were included in all the assays for quality control. All the isolates were stored in nutrient agar as stabs at room temperature. The presumptively identified $A$. hydrophila isolates were positive for biochemical traits including $o$-nitrophenylgalactoside, DNase, catalase, growth in 0 and $1 \% \mathrm{NaCl}$, gas from fermented glucose, acid production from D-mannitol, D-galactose and maltose, nitrate reduction, motility and GCF $\left(\mathrm{H}_{2} \mathrm{~S}\right.$ from cysteine), and invariably negative for ornithine decarboxylase, tryptophan deaminase, utilization of glycine, $\mathrm{H}_{2} \mathrm{~S}$ production in triple-sugar iron agar (TSI) and growth in $7 \% \mathrm{NaCl}$ (Abbott et al., 2003). Variable results were obtained in the following tests: acid production from glycerol and mannose, $\mathrm{N}$-acetylglucosamine, and utilization of acetate and citrate, Voges-Proskauer (VP) test, lysine decarboxylase (LDC), DL-lactate, gelatinase, aesculin hydrolysis, and acid from mannose, sucrose, arabinose and cellobiose (Abbott et al., 2003). All of the environmental isolates except strain PC25 showed a negative string reaction. All were positive for arginine dihydrolase (ADH) except for two isolates, PC48 and PC68. Although A. hydrophila isolates generally give a positive result for $\mathrm{ADH}, \mathrm{ADH}$-negative A. hydrophila isolates were reported in an earlier study (Altwegg et al., 1990). The positive activities for LDC, DNase, DL-lactate, aesculin hydrolysis and gelatinase differentiate $A$. hydrophila from A. sobria (ADH-negative) (Altwegg et al., 1990; Abbott et al., 2003). The positive activities for GCF, production of gas from glucose and gluconate oxidation distinguish $A$. hydrophila from $A$. caviae and A. media which are ADH-negative (Abbott et al., 2003). Aeromonas veronii biovar Veronii (ADH-negative) is able to decarboxylate ornithine.

Clinical isolates. Five isolates of A. hydrophila (AN1, AN2, AN37, AE53 and AE55) and one strain each of $V$. cholerae O1 (NB2) and O139 (SG24) serogroups isolated from hospitalized patients with acute diarrhoea in Kolkata, India, were included in this study.

PCR. The amplification of target genes was carried out by PCR using bacterial cell lysate as the source of template DNA (Bag et al., 2008). Amplification was performed in a thermal cycler (Eppendorf Mastercycler) using $200 \mu \mathrm{l}$ PCR tubes with a reaction mixture volume of $25 \mu \mathrm{l}$. PCRs for detecting the genes encoding Aeromonas cytotoxic enterotoxin (act) (Kingombe et al., 1999), Aeromonas haemolysin (hlyA) (Heuzenroeder et al., 1999), A. caviae haemolysin (Wang et al., 1996), variants of aerolysin (Pollard et al., 1990), Aeromonas heat-stable cytotonic enterotoxins (ast) (Sha et al., 2002, Sinha et al., 2004), Shiga toxin variants of Escherichia coli (Khan et al., 2002), V. cholerae outer-membrane protein (ompW) (Nandi et al., 2000) and cholera toxin subunit A (ctxA) (Keasler \& Hall, 1993) were done as described elsewhere (Pollard et al., 1990; Keasler \& Hall, 1993; Wang et al., 1996, Heuzenroeder et al., 1999; Kingombe et al., 1999; Nandi et al., 2000). Strain A. hydrophila SSU (Albert et al., 2000) was used as positive control for ast and act. The sequences of the primers used are listed in Supplementary Table S1, available in JMM Online.

PCR products were electrophoresed through $2 \%(\mathrm{w} / \mathrm{v})$ agarose gel to resolve the amplified products, which were visualized under UV light after ethidium bromide staining. 
Preparation of cell-free culture supernatants. Trypticase soy broth (TSB; HiMedia) was used for assessing production of various toxins. The test isolates were grown in TSB at $37^{\circ} \mathrm{C}$ with shaking (200 r.p.m.) for $18 \mathrm{~h}$. After centrifugation (15000 $g$ for $20 \mathrm{~min}$ at $4{ }^{\circ} \mathrm{C}$ ), the culture supernatant was filtered using a $0.22 \mu \mathrm{m}$ filter (Millipore) and the cell-free filtrate was used for the tissue culture and haemolysin assays.

Tissue culture assay. The tissue culture assay was performed using HeLa cells as described previously (Bag et al., 2008). Morphological changes and cytotoxic effects were recorded after $24 \mathrm{~h}$ incubation using an inverted microscope (Olympus).

Adherence assay. Isolates were examined for their adherence to HeLa cells as described previously (Cravioto et al., 1979; Bag et al., 2008). The adhesion index was determined as the percentage of epithelial cells with adhering bacteria; if at least $40 \%$ of the HeLa cells had adhering bacteria, the strain was considered to be positive (Cravioto et al., 1979).

\section{Assay of haemolysin and cell-associated haemagglutinating activity. Haemolytic and cell-associated haemagglutinating activity of the isolates with human erythrocytes was determined as described previously (Ramamurthy et al., 1993). The amount of released haemoglobin in the supernatant was measured spectrophotometri- cally (U-3210; Hitachi) at $540 \mathrm{~nm}$. PBS and blood cells lysed (100\%) with an equal volume of Triton X-100 solution served as negative and positive controls, respectively.}

Detection of extracellular enzymes. Proteolytic (gelatinase and HA/protease) and lipolytic (lipase) activities were examined by the plate assay method (West \& Colwell, 1984). A clear zone around a bacterial colony indicated a positive result. A known strain of $V$. cholerae $\mathrm{O} 1$ for gelatinase and $\mathrm{HA} /$ protease, and Pseudomonas aeruginosa for lipase were included as positive controls.

Serum resistance test. The susceptibility of bacteria to human serum was determined as described previously (Bag et al., 2008), following the method of Hughes et al. (1982). Responses were graded as highly sensitive, intermediately sensitive or serum-resistant, according to the system of Hughes et al. (1982).

Antimicrobial susceptibility test. Antimicrobial susceptibility testing was performed by the disk diffusion method (Bauer et al., 1966) with commercially available disks (HiMedia) of 12 antimicrobial drugs on Mueller-Hinton agar (HiMedia). Isolates were considered susceptible, reduced susceptible or resistant to a particular antimicrobial agent on the basis of the diameters of the inhibitory zones that matched the criteria of the manufacturer's interpretive table, which followed the recommendations of the National Committee for Clinical Laboratory Standards (NCCLS, 2002). E. coli ATCC 25922 was used for quality control.

Enteropathogenicity assay. The enteropathogenicity of the isolates was examined as described previously (Bag et al., 2008) using the sealed-adult-mouse model of Richardson et al. (1984) using Swiss albino mice weighing about $15-20 \mathrm{~g}$. The animals, kept in wire-mesh polycarbonate cages with autoclaved bedding, were acclimated to laboratory conditions ( $12 \mathrm{~h}$ dark: $12 \mathrm{~h}$ light cycles; $\left.24 \pm 1{ }^{\circ} \mathrm{C}\right)$ and had free access to food and water ad libitum. Animal use and the care protocol were approved by the university animal ethics committee, University of Calcutta. At $5 \mathrm{~h}$ post-inoculation, mice were sacrificed and fluid accumulation (FA) ratios were determined (Richardson et al., 1984). FA ratios of $\geqslant 100$ were considered positive. For the colonization assay, infections were allowed to proceed for $18 \mathrm{~h}$. The mice were sacrificed and their intestines were aseptically removed. Sections from the intestine were washed with PBS to remove unbound bacteria, weighed and homogenized in PBS. Various dilutions of these homogenates were plated onto TCBS agar and incubated at $37{ }^{\circ} \mathrm{C}$ for $24 \mathrm{~h}$. Colony-forming units were counted and colonization is expressed as $\log _{10}$ [c.f.u. $(\mathrm{g} \text { tissue })^{-1}$ ]. Isolates passaged through the mouse gut were recovered from the intestine on TCBS agar plates, and following overnight incubation, approximately five to six colonies were inoculated into peptone water and incubated at $37{ }^{\circ} \mathrm{C}$ for $4 \mathrm{~h}$. Approximately $2 \times 10^{10}$ c.f.u. bacterial inoculum $\mathrm{ml}^{-1}$ was fed to mice and FA ratios and colonization were determined as described above.

Histopathology. Histopathology was performed using Swiss albino mice as described by Chang \& Miller (2006). After $18 \mathrm{~h}$ postinoculation, mice were euthanized and sections of small intestine were immediately fixed in $10 \%$ neutral buffer formalin. Following fixation, tissue samples were embedded in paraffin, sectioned at $5 \mu \mathrm{m}$ and stained with haematoxylin-eosin for light microscopic examination.

\section{RESULTS}

One hundred and thirty-nine samples of natural surface water were collected from 16 sites located in different diarrhoea-endemic zones in and around Kolkata. Thirtyfive $(25 \%)$ of the samples contained presumptive $A$. hydrophila, and this species was isolated from surface waters in 6 of 16 sites sampled (Rajarhat, Dum Dum, Taratala, Canning, Deulti and Budge Budge). All the isolates were Gram-negative, rod-shaped and positive for oxidase. None of them were positive for $V$. cholerae-specific ompW in the PCR assay, excluding the possibility of misidentification of $V$. cholerae as Aeromonas species. All the isolates grew on TCBS agar forming either yellow or bluish-green colonies, and gave alkaline slant/acid butt reactions in multi-test medium (mannitol-positive and ornithine decarboxylase-negative) (Kaper et al., 1979). Of the 100 presumptively identified $A$. hydrophila isolates, 21 were randomly selected, taking at least two isolates from each site for further characterization. These isolates were identified as A. hydrophila by the criteria described in Methods.

Four and two of the environmental and clinical isolates of A. hydrophila, respectively, were determined to be positive for act by PCR (Table 1$)$. However, the majority $(81 \%)$ of the isolates produced a cytotoxic response to HeLa cells with an end-point titre of 16-256 (reciprocal of dilution of TSB culture filtrate producing cytotoxic effect on $\geqslant 50 \%$ of cells) (Fig. 1, Table 1). None of the isolates demonstrated a cytotonic effect and was positive for ast in the PCR assay. The majority of the adherence-positive $A$. hydrophila isolates manifested diffused adhesion and three of the isolates showed localized adhesion on HeLa cells (Fig. 2).

Eighteen environmental and three clinical isolates of $A$. hydrophila were examined for their enteropathogenic potential in the sealed-adult-mouse model using live bacterial cells. Toxigenic strains of $V$. cholerae O139 (SG24) and O1 (NB2) were used for comparison. Of the 18 environmental isolates, 16 induced positive FA $(\geqslant 100)$, and the reactivities of these isolates were comparable to 
Table 1. Virulence phenotypes of environmental and clinical isolates of $A$. hydrophila

+ , Positive; -, negative; ND, not determined.

\begin{tabular}{|c|c|c|c|c|c|c|c|c|c|c|c|}
\hline Source & Strain & $\begin{array}{l}\text { Cytotoxic } \\
\text { activity } \\
\text { (end-point } \\
\text { titre })^{\star}\end{array}$ & $\begin{array}{l}\text { Presence } \\
\text { of } a c t \dagger\end{array}$ & $\begin{array}{c}\text { Haemolysin } \\
\text { activity } \\
\left(\mathrm{OD}_{540}\right) \ddagger\end{array}$ & $\begin{array}{l}\text { Presence } \\
\text { of } h l y A \dagger\end{array}$ & $\begin{array}{l}\text { Lipase } \\
\text { activity }\end{array}$ & $\begin{array}{l}\text { Protease } \\
\text { activity }\end{array}$ & $\begin{array}{c}\text { HA } \\
\text { activity } \$\end{array}$ & $\begin{array}{c}\text { Serum } \\
\text { sensitivity } \\
\text { grade } \|\end{array}$ & Adherence & $\begin{array}{c}\text { Resistant/ } \\
\text { reduced } \\
\text { susceptibility }\end{array}$ \\
\hline \multirow{21}{*}{$\begin{array}{l}\text { Environ- } \\
\text { ment }\end{array}$} & PC16 & 256 & - & $13(0.2)$ & - & + & - & - & $5-6$ & - & $\mathrm{Ch} \mathrm{Fz} / \mathrm{T} \mathrm{N} \mathrm{Nx}$ \\
\hline & PC17 & 128 & - & $100(1.6)$ & - & + & + & + & $5-6$ & Diffuse & Ch A T Fz/- \\
\hline & PC18 & 64 & + & $94(1.5)$ & - & + & + & - & $5-6$ & Localized & $\mathrm{A} / \mathrm{T} \mathrm{Fz} \mathrm{Co}$ \\
\hline & PC19 & 128 & - & $6(0.1)$ & - & - & - & - & $1-2$ & - & T/A Na Ch \\
\hline & PC20 & 256 & - & $13(0.2)$ & - & + & - & - & $3-4$ & Diffuse & Ch A S G/T N Fz \\
\hline & PC21 & 64 & + & $94(1.5)$ & - & + & + & + & $3-4$ & Localized & $\mathrm{A} \mathrm{Fz/T} \mathrm{N}$ \\
\hline & PC22 & 64 & - & $6(0.1)$ & - & + & + & ++ & $3-4$ & Diffuse & A Fz/N \\
\hline & PC23 & 128 & - & $100(1.6)$ & + & + & + & + & $5-6$ & Diffuse & $\begin{array}{l}\text { Ch Na/A T N G } \\
\qquad z\end{array}$ \\
\hline & PC24 & 64 & - & $6(0.1)$ & - & + & + & + & $1-2$ & Diffuse & A S/T N Fz \\
\hline & PC25 & 32 & - & $6(0.1)$ & - & + & + & + & $3-4$ & Diffuse & A T Fz/N Ch \\
\hline & PC27 & 32 & - & $0(0.0)$ & - & + & + & - & $5-6$ & - & Ch A/T N G Fz \\
\hline & PC28 & 32 & - & $0(0.0)$ & - & - & + & + & $3-4$ & Diffuse & A T Fz Co/N \\
\hline & PC30 & 64 & - & $0(0.0)$ & - & + & - & - & $3-4$ & - & $\begin{array}{l}\text { Ch A/T S N Fz } \\
\mathrm{Nx}\end{array}$ \\
\hline & PC48 & - & - & $0(0.0)$ & - & - & - & - & $5-6$ & - & A \\
\hline & PC58 & 32 & - & $0(0.0)$ & - & + & - & - & $5-6$ & Diffuse & Ch A Fz/T \\
\hline & PC60 & - & + & $0(0.0)$ & - & + & - & - & $3-4$ & - & $\mathrm{Ch} \mathrm{A} \mathrm{Na/Fz}$ \\
\hline & PC68 & - & - & $6(0.1)$ & + & - & - & - & $5-6$ & - & $\mathrm{A} \mathrm{T} \mathrm{/Fz} \mathrm{Ch}$ \\
\hline & PC72 & - & - & $13(0.2)$ & + & - & - & - & $5-6$ & - & $\mathrm{A} \mathrm{Ch}$ \\
\hline & PC81 & 128 & - & $63(1.0)$ & - & + & + & - & $5-6$ & Diffuse & $\mathrm{Ch} \mathrm{A} / \mathrm{Fz}$ \\
\hline & PC94 & 16 & + & $6(0.1)$ & + & + & + & + & $5-6$ & Diffuse & A Fz/N \\
\hline & PC95 & 64 & - & $88(1.4)$ & - & + & + & + & $3-4$ & Localized & A Fz/T N \\
\hline \multirow[t]{5}{*}{ Clinical } & AN1 & 16 & - & $56(0.9)$ & + & + & + & + & $5-6$ & Diffuse & Ch A Na Fz/-\# \\
\hline & AN2 & 16 & - & $56(0.9)$ & + & + & + & ++ & $5-6$ & $\mathrm{ND}$ & Ch A Na Nx\# \\
\hline & AN37 & 64 & + & $56(0.9)$ & - & + & + & + & $3-4$ & $\mathrm{ND}$ & A S/-\# \\
\hline & AE53 & 64 & + & $56(0.9)$ & + & + & + & ++ & $3-4$ & Diffuse & Ch A Na S/-\# \\
\hline & AE55 & 16 & - & $56(0.9)$ & + & + & + & - & $3-4$ & ND & $\begin{array}{l}\text { A Na Fz S Co } \\
\text { Ch\# }\end{array}$ \\
\hline
\end{tabular}

${ }^{\star}$ Reciprocal of dilution of TSB culture filtrate producing a cytotoxic effect in $\geqslant 50 \%$ of HeLa cells.

$\dagger a c t$ and $h l y A$ gene sequences were detected by PCR.

$\ddagger$ TSB culture filtrate was mixed $1: 1$ with human erythrocytes suspended in PBS and incubated at $37{ }^{\circ} \mathrm{C}$ for $1 \mathrm{~h}$. The released haemoglobin was measured spectrophotometrically. An $\mathrm{OD}_{540}$ value of $\geqslant 0.1$ was considered to be a positive result for haemolysin. Haemolysin activities are expressed as the percentage of lysis by comparing the $\mathrm{OD}_{540}$ value with that of an identical erythrocyte suspension lysed (100\%) with an equal volume of Triton X-100 solution.

$\S$ Cell-associated haemagglutinating (HA) activity was determined using pooled group O human blood cells. ++ , Immediate reaction; + , reaction was incomplete or not instantaneous, but occurred within $5 \mathrm{~min}$; -, no agglutination.

IIGrades: 5-6, resistant; 3-4, intermediately (delayed) sensitive; 1-2, completely sensitive to human normal serum (Hughes et al., 1982).

SA, ampicillin $(10 \mu \mathrm{g}) ; \mathrm{C}$, chloramphenicol $(30 \mu \mathrm{g}) ; \mathrm{T}$, tetracycline $(30 \mu \mathrm{g}) ; \mathrm{S}$, streptomycin $(10 \mu \mathrm{g}) ; \mathrm{N}$, neomycin $(30 \mu \mathrm{g}) ; \mathrm{G}$, gentamicin $(10 \mu \mathrm{g})$; $\mathrm{Na}$, nalidixic acid $(30 \mu \mathrm{g}) ; \mathrm{Fz}$, furazolidone $(100 \mu \mathrm{g})$; Nx, norfloxacin $(10 \mu \mathrm{g})$; Co, co-trimoxazole $(25 \mu \mathrm{g})$; Ch, cephalothin $(30 \mu \mathrm{g})$.

\#Sinha et al. (2004).

those of clinical strains of A. hydrophila (Table 2). A comparison of counts of the colonized environmental and clinical isolates in mouse intestines showed that the isolates of both groups had almost the same colonization potential. Colonization of A. hydrophila and V. cholerae, expressed as $\log _{10}\left[\right.$ mean c.f.u. (g tissue) $\left.{ }^{-1} \pm \mathrm{SD}\right]$, ranged between $3.13 \pm 0.82$ and $6.56 \pm 0.32$ (Table 2). Exposure of mouse intestine to the environmental isolates of $A$. hydrophila caused epithelial damage of villi associated with architectural distortion of crypt and infiltration of polymorphonuclear cells extending through the mucus (Fig. 3). 

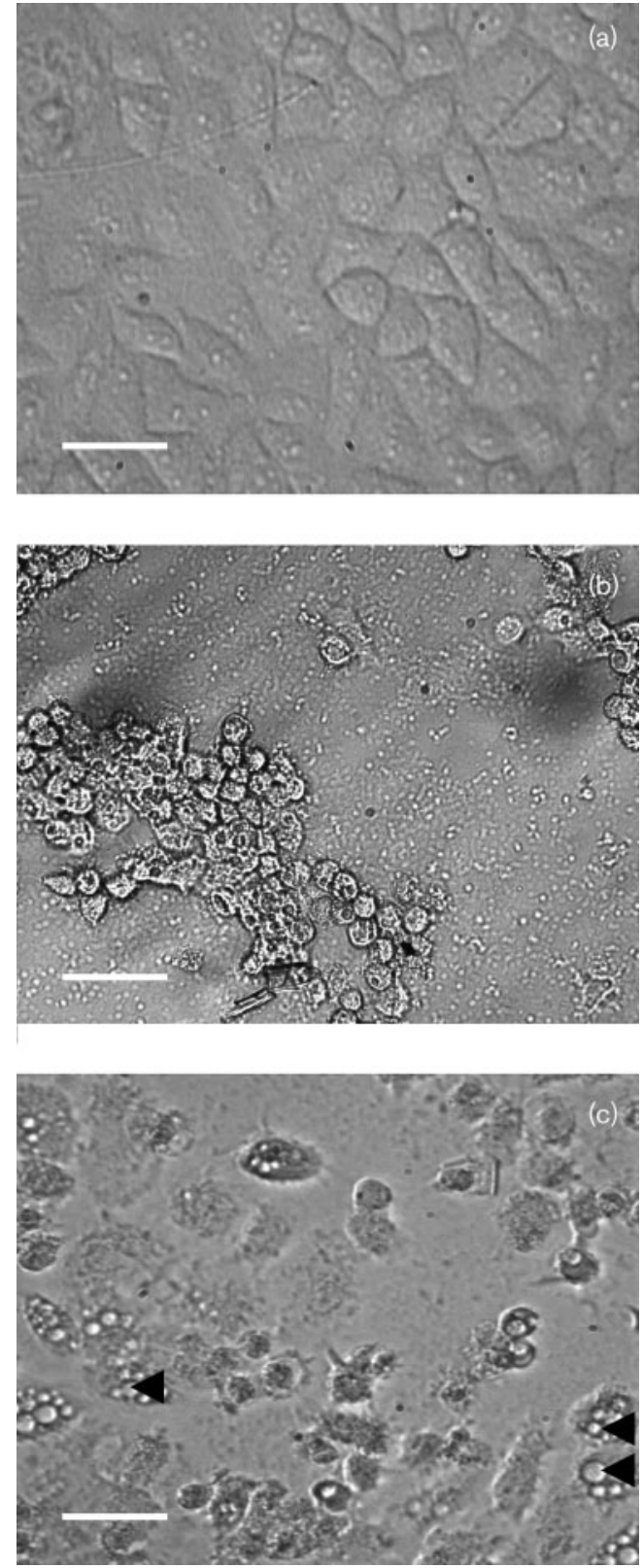

Fig. 1. Effects of culture filtrates of environmental isolates of $A$. hydrophila on HeLa cells. (a) Confluent growth of HeLa cells; (b) cytotoxic effect; (c) cytotoxic effect associated with cell vacuolation (indicated by arrowheads). Bars, $25 \mu \mathrm{m}$.

\section{DISCUSSION}

Cytotoxin plays an important role in the pathogenicity of enteric bacteria (Nataro et al., 2003). In this study, two $A$. hydrophila isolates (PC24 and PC25), evoked a cellvacuolating effect, which is in agreement with other studies (Di Pietro et al., 2005). Furthermore, these two isolates were able to induce FA in mouse intestine. Previous reports indicated that aerolysin is a pore-forming toxin secreted by human pathogen $A$. hydrophila that causes vacuolation in
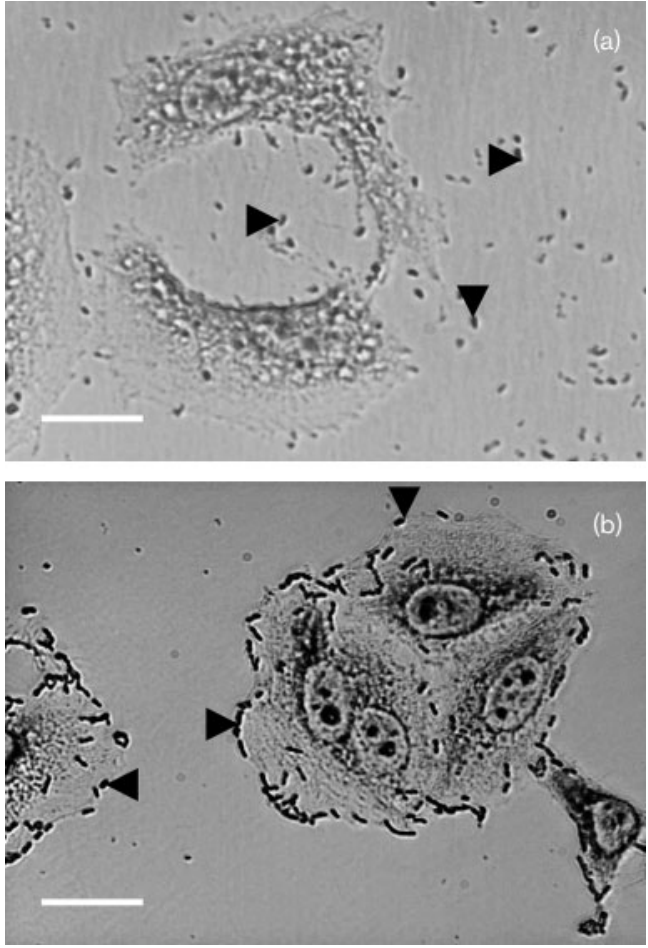

Fig. 2. Adherence patterns of environmental isolates of $A$. hydrophila on HeLa cells (Giemsa stain). (a) Diffuse adherence; bacteria are dispersed over the cell surface and the cell matrix. (b) Localized adherence-like adherence. Arrowheads indicate bacterial cells. Bars, $25 \mu \mathrm{m}$.

the cytoplasm of baby hamster kidney cells (Abrami et al., 1998). However, none of our isolates were positive for aer sequences (encoding aerolysin) in the PCR assay. Therefore, we suggest that the vacuolating cytotoxin of $A$. hydrophila in the present study may be different from aerolysin. Furthermore, strains of Vibrio fluvialis are also capable of producing a vacuolation effect in HeLa cells (Chakraborty et al., 2005), and exhibit biochemical traits typical for the genus with a few features resembling Aeromonas. In many cases, the API20E system identified $V$. fluvialis strains as A. hydrophila, with high identification scores (Seidler et al., 1980). Therefore, we included a salttolerance test to distinguish $A$. hydrophila strains from $V$. fluvialis. $V$. fluvialis cannot grow in $1 \%$ peptone without $\mathrm{NaCl}$, but can grow in the same medium with $7 \% \mathrm{NaCl}$. However, strains PC24 and PC25 grew well in broth containing $1 \%$ peptone without $\mathrm{NaCl}$ and did not grow with $7 \% \mathrm{NaCl}$. In addition, these isolates were able to produce gas from glucose. $V$. fluvialis does not produce gas from glucose, thus resembling $V$. cholerae.

Although one (PC60) of our act-positive isolates did not show cytotoxicity to HeLa cells, all of the act-positive isolates caused FA, epithelial damage of villi and infiltration of polymorphonuclear cells extending through the mucus in mouse intestine. This is in agreement with 
Table 2. Enteropathogenicity of some environmental and clinical isolates in the mouse model

\begin{tabular}{|c|c|c|c|c|c|c|c|}
\hline Source & Species & Strain & Wild-type strain ${ }^{\star}$ & $\begin{array}{c}\text { Animal-passaged } \\
\text { strain }^{\star}\end{array}$ & Wild-type $\dagger$ & $\begin{array}{c}\text { Animal-passaged } \\
\text { strain } \dagger\end{array}$ & $\begin{array}{l}\text { Increase in } \\
\text { FA ratio (\%) }\end{array}$ \\
\hline \multirow[t]{13}{*}{ Environment } & A. hydrophila & PC16 & $3.60 \pm 0.42$ & ND & $142.50 \pm 0.50$ & ND & \\
\hline & & PC17 & $4.02 \pm 0.19$ & ND & $134.74 \pm 11.90$ & ND & \\
\hline & & PC18 & $3.85 \pm 0.16$ & $5.54 \pm 0.31$ & $121.35 \pm 2.85$ & $122.67 \pm 10.34$ & 1.08 \\
\hline & & PC20 & $4.51 \pm 1.02$ & $\mathrm{ND}$ & $189.70 \pm 46.60$ & $\mathrm{ND}$ & \\
\hline & & PC21 & $3.49 \pm 0.30$ & ND & $81.85 \pm 1.35$ & ND & \\
\hline & & PC22 & $4.28 \pm 0.32$ & $6.21 \pm 0.06$ & $75.7 \pm 17.56$ & $158.63 \pm 2.39$ & 109.55 \\
\hline & & PC23 & $3.97 \pm 0.14$ & $6.31 \pm 0.13$ & $111.17 \pm 2.93$ & $159.89 \pm 24.87$ & 43.82 \\
\hline & & PC24 & $5.38 \pm 0.96$ & $5.605 \pm 0.31$ & $137.50 \pm 41.50$ & $141.47 \pm 34.55$ & 2.88 \\
\hline & & PC25 & $4.07 \pm 0.17$ & $5.68 \pm 0.05$ & $150.57 \pm 42.93$ & $164.83 \pm 50.40$ & 9.47 \\
\hline & & PC68 & $4.17 \pm 0.17$ & $4.78 \pm 0.16$ & $132.68 \pm 19.96$ & $121.43 \pm 1.71$ & $-8.47 \ddagger$ \\
\hline & & PC72 & $4.08 \pm 0.16$ & $\mathrm{ND}$ & $125.46 \pm 2.85$ & ND & \\
\hline & & PC81 & $4.05 \pm 0.02$ & ND & $109.48 \pm 20.14$ & ND & \\
\hline & & PC95 & $4.92 \pm 1.52$ & ND & $120.9 \pm 13.65$ & ND & \\
\hline \multirow[t]{5}{*}{ Clinical } & A. hydrophila & AN1 & $4.22 \pm 0.41$ & $\mathrm{ND}$ & $104.0 \pm 21.0$ & ND & \\
\hline & & AN2 & $5.69 \pm 0.03$ & $6.51 \pm 0.15$ & $87.14 \pm 8.52$ & $124.83 \pm 3.69$ & 43.25 \\
\hline & & AE53 & $4.93 \pm 0.07$ & $\mathrm{ND}$ & $116.50 \pm 30.50$ & $\mathrm{ND}$ & \\
\hline & V. cholerae & NB2 & $4.77 \pm 0.87$ & $\mathrm{ND}$ & $147.55 \pm 15.55$ & $\mathrm{ND}$ & \\
\hline & & SG24 & $6.56 \pm 0.32$ & ND & $152.75 \pm 34.25$ & ND & \\
\hline PBS control & - & - & - & - & $55.75 \pm 5.26$ & - & - \\
\hline
\end{tabular}

ND, Not determined.

${ }^{*}$ Values are expressed as $\log _{10}\left[\right.$ c.f.u. (g tissue) ${ }^{-1}$ ] and represent the mean data \pm SD from 3-5 adult Swiss albino mice.

$\dagger$ Values are expressed as FA ratios and represent the mean data \pm sD from 3-5 adult Swiss albino mice.

$\ddagger$ Decrease in FA ratio.

previous findings which indicated that Aeromonas cytotoxic enterotoxin (Act) induces production of proinflammatory cytokines associated with Act-induced tissue injury (Chopra et al., 2000). A. hydrophila produces an Act that is related to aerolysin and has haemolytic, cytotoxic and enterotoxic activity (Chopra \& Houston, 1999). Although all of our act-positive isolates caused FA, some of them were non-haemolytic or poorly haemolytic. A. hydrophila may also produce Shiga-like toxin 1, or at least a cytotoxin with some homology to the Shiga-like toxin 1 of E. coli O157:H7 (Haque et al., 1996). Evidence for production of cholera toxin cross-reactive factor by A. hydrophila had also been documented (Chopra et al., 1986). When tested by PCR, all the tested A. hydrophila isolates were negative for genes encoding Shiga toxin and cholera toxin.

In the present study, it was found that the majority ( $71 \%)$ of the environmental isolates of A. hydrophila produced haemolysin. However, only four of them were positive for hlyA in the PCR assay (Table 1). Additionally, none of the clinical or environmental isolates were positive for $A$. caviae-specific hly genes. Three isolates of A. hydrophila
(PC27, PC28 and PC30) that were negative for haemolysin production were found to evoke a cytotoxic effect on HeLa cells. Furthermore, haemolysin production was not correlated with cytotoxic activity in the present study $(P>0.05)$. One study has shown that 11 toxin-positive A. hydrophila strains from Ethiopia were compared to toxin-negative strains from India, using the API 20E system for biotyping (Ljungh et al., 1977). In that study, no correlation between biotype and toxin production was found, although specific results of LDC and VP tests were not stated. However, another group (Cumberbatch et al., 1979) established a correlation between toxigenicity and LDC- and VP-positive phenotypes. The significance of the relationship between an LDC- and/or VP-positive phenotype and toxigenicity is still unknown. The association of enterotoxigenicity and raffinose fermentation in porcine E. coli appears to be related to these properties being mediated by the same plasmid, rather than any intrinsic requirement for raffinose fermentation in the biosynthesis of enterotoxin (Schneider \& Parker, 1978). However, in the present study, we did not find any correlation between cytotoxin production and various biotypes such as LDC, VP, utilization of citrate and 

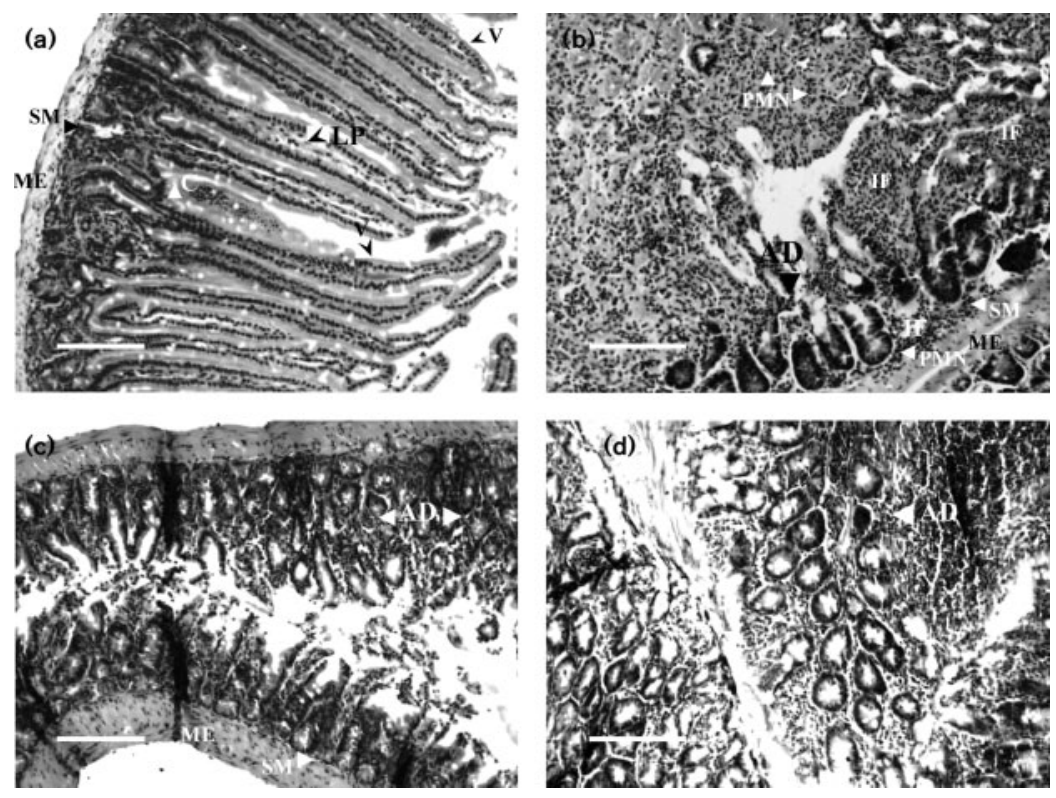

Fig. 3. Histopathology of small intestine tissue from Swiss albino mice $18 \mathrm{~h}$ post-inoculation. (a) Control small intestine tissue from an uninfected mouse, showing normal crypt and villous architecture, with only a small number of inflammatory cells in the lamina propria. (b, c and d) Severe inflammation of the mucosa and submucosa in the small intestine was observed in mice $18 \mathrm{~h}$ post-inoculation with (b) $A$. hydrophila strain PC24 (environmental), (c) $A$. hydrophila strain AN2 (clinical) and (d) V. cholerae strain NB2. In each case, cellular infiltrate, consisting largely of polymorphonuclear cells, extends through the muscularis mucosa and submucosa. Epithelial damage of the villi is extensive and this damage extends into the crypt. Architectural distortion, epithelial hyperplasia and loss of goblet cells were also observed. Abbreviations: AD, architectural distortion; C, crypt; IF, intense inflammatory infiltrate; LP, lamina propria; ME, muscularis externa; PMN, polymorphonuclear cells; SM, submucosa; V, villi. Bars, $100 \mu \mathrm{m}$. acetate, and fermentation of sucrose, cellobiose and salicin. Correlation of various biochemical characteristics with cytotoxin production and adherence for environmental isolates is shown in Supplementary Table S2, available in JMM Online. Although the precise roles of protease, gelatinase and lipase in vivo are not yet clear, we found that protease, gelatinase or lipase activities were significantly correlated with cytotoxin production $(P<0.05)$ in the environmental isolates. Lecithinase (phospholipase $C$ ) was shown to be cytotoxic, but non-haemolytic or poorly haemolytic (Merino et al., 1999). This is in agreement with our experience with $A$. hydrophila isolates. We found a good correlation between lipase activities and cytotoxin production $(P<0.05)$, but this did not correlate with haemolysin activities $(P>0.05)$. The findings of another study revealed that the majority of clinical isolates of $A$. hydrophila showed localized adhesion to intestinal 407 cells, whereas environmental isolates showed diffused adhesion (Krovacek et al., 1994). Although the majority of the adherence-positive A. hydrophila isolates manifested diffused adhesion, three of the isolates showed localized adhesion on HeLa cells in our study. Furthermore, a very good correlation exists between adherence and either protease or haemagglutinating activity $(P<0.005)$. Haemolysin activity did not correlate with adherence property. However, adherence to HeLa cells did correlate with the VP biotype $(P<0.05)$.

In our study, the majority $(90 \%)$ of the isolates showed serum resistance properties (grade 5 and 6 or grade 3 and 4), comparable with clinical isolates. Lawson et al. (1985) indicated that some of the clinical isolates of A. hydrophila are invasive in HEp-2 cells. Additionally, the bactericidal activity of antibodies and 'complement-like' bactericidal activity is operative in the intestinal mucosa, contributing to the colonization properties of a variety of bacterial pathogens (Parsot et al., 1991). Hence, the serum resistance properties of $A$. hydrophila could also play an essential role in intestinal colonization. It has been suggested that the ability of some A. hydrophila strains to resist complementmediated killing could result in bacteraemia and other invasive diseases associated with Aeromonas infection (Merino et al., 1996).

A previous study revealed that most of the Kolkata $A$. hydrophila strains (clinical) included in the study showed resistance to ampicillin, nalidixic acid, cephalothin, streptomycin and furazolidone (Sinha et al., 2004). In the present study, the environmental isolates of $A$. hydrophila were resistant or had reduced susceptibility to ampicillin (93\%), furazolidone (93\%), tetracycline (93\%), neomycin (71\%), cephalothin (62\%), streptomycin (18\%) and nalidixic acid (14\%). Emergence of multiple resistance is a serious clinical problem in the treatment and containment of disease. Although clinical isolates of A. hydrophila have been reported to be resistant to ampicillin, one isolate (PC16) was sensitive to ampicillin and this finding agrees with the earlier isolation of an ampicillin-sensitive strain of A. hydrophila from a water sample (Rippey \& Cabelli, 1979). In one earlier study, it was shown that nalidixic acid resistance $(72 \%)$ was much more frequent than tetracycline $(21 \%)$ or co-trimoxazole $(14 \%)$ resistance among environmental isolates of Aeromonas (Goñi-Urriza et al., 2000). Other studies have demonstrated that quinolone resistance was less than $25 \%$ among environmental isolates (McKeon et al., 1995). In the present study, furazolidone (93\%) or tetracycline $(93 \%)$ resistance were much more frequent than nalidixic acid resistance (14\%). The 
identification of this diversity of resistance among Aeromonas isolates from the aquatic environment led us to the conclusion that these Aeromonas isolates may serve as a reservoir of antibiotic resistance genes, and the resistance may be transferred to other bacteria in the environment as well (Henriques et al., 2006). The prevalence and transmission of multi-drug resistance among clinical and environmental isolates of Aeromonas has been documented by several authors (Miranda \& Castillo, 1998; GoñiUrriza et al., 2000; Henriques et al., 2006; Rahman et al., 2009). In many studies, an increase in resistance was observed among strains of Aeromonas isolated from rivers receiving urban discharge (Bhattacherjee et al., 1988; Ko et al., 1996; Goñi-Urriza et al., 2000). In our study, a higher prevalence of multiple resistances was observed, and this might be due to the fact that urban or rural effluents, including industrial effluent or raw sewage, etc., in developing countries are known to contain high levels of antibiotics and antibiotic-resistant bacteria belonging to the human and animal commensal flora (Bhattacherjee et al., 1988; Goñi-Urriza et al., 2000; Kathuria, 2006).

It was interesting to note that some of the environmental isolates showed enterotoxic activity and colonization in mouse intestine comparable to those of clinical isolates of $A$. hydrophila and toxigenic $V$. cholerae. Environmental isolates showed an increase in FA from 1.08 to $109.55 \%$ and a level of colonization between 0.23 and 3.13 $\log _{10}$ [c.f.u. (g tissue) $)^{-1}$ ] after passage through the mouse intestine (Table 2). Except for serum resistance, one (PC48) of the isolates was negative for the putative virulence traits tested in this study. However, this isolate showed positive FA and efficient colonization in the mouse intestine. This effect may be due to the presence of another unknown enterotoxin. Damage to the mouse intestine and the inflammatory reaction caused by the environmental isolates were comparable to those of clinical strains of $A$. hydrophila and toxigenic V. cholerae (Fig. 2). Therefore, it can be suggested that $A$. hydrophila can produce cytotoxic substance(s) and causes FA and destruction of intestinal mucosa resembling the activity of toxigenic $V$. cholerae. Although it is still unclear which virulence factor(s) of $A$. hydrophila is responsible for causing diarrhoea in humans, we propose that environmental isolates of this species may be a potential enteric pathogen, and that continuous monitoring is needed to explicate the ecology and the public health significance of $A$. hydrophila.

\section{ACKNOWLEDGEMENTS}

The fellowships of P. B. and T. K. H. were provided by the University Grants Commission, India.

\section{REFERENCES}

Abbott, S. L., Cheung, W. K. \& Janda, J. M. (2003). The genus Aeromonas: biochemical characteristics, atypical reactions, and phenotypic identification schemes. J Clin Microbiol 41, 2348-2357.
Abrami, L., Fivaz, M., Glauser, P. E., Parton, R. G. \& Van der Goot, F. G. (1998). A pore-forming toxin interacts with a GPI-anchored protein and causes vacuolation of the endoplasmic reticulum. J Cell Biol 140, 525-540.

Agger, W. A., McCormick, J. D. \& Gurwith, M. J. (1985). Clinical and microbiological features of Aeromonas hydrophila-associated diarrhoea. J Clin Microbiol 21, 909-913.

Albert, M. J., Ansaruzzaman, M., Talukder, K. A., Chopra, A. K., Kühn, I., Rahman, M., Faruque, A. S. G., Islam, M. S., Sack, R. B. \& Möllby, R. (2000). Prevalence of enterotoxin genes in Aeromonas spp. isolated from children with diarrhea, healthy controls, and the environment. J Clin Microbiol 38, 3785-3790.

Altwegg, M., Steigerwalt, A. G., Altwegg-Bissig, R., LüthyHottenstein, J. \& Brenner, D. J. (1990). Biochemical identification of Aeromonas genospecies isolated from humans. J Clin Microbiol 28, 258-264.

Bag, P. K., Bhowmik, P., Hajra, T. K., Ramamurthy, T., Sarkar, P., Majumder, M., Chowdhury, G. \& Das, S. C. (2008). Putative virulence traits and pathogenicity of Vibrio cholerae non-O1, non-O139 isolated from surface waters in Kolkata, India. Appl Environ Microbiol 74, 5635-5644.

Bauer, A. W., Kirby, W. M., Sherris, J. C. \& Jurck, M. (1966). Antibiotic susceptibility testing by a standardized single disk method. Am J Clin Pathol 45, 493-496.

Bhattacherjee, J. W., Pathak, S. P. \& Gaur, A. (1988). Antibiotic resistance and metal tolerance of coliform bacteria isolated from Gomati River water at Lucknow city. J Gen Appl Microbiol 34, 391399.

Chakraborty, R., Chakraborty, S., De, K., Sinha, S., Mukhopadhyay, A. K., Khanam, J., Ramamurthy, T., Takeda, Y., Bhattacharya, S. K. \& Nair, G. B. (2005). Cytotoxic and cell vacuolating activity of Vibrio fluvialis isolated from paediatric patients with diarrhoea. J Med Microbiol 54, 707-716.

Chang, C. \& Miller, J. F. (2006). Campylobacter jejuni colonization of mice with limited enteric flora. Infect Immun 74, 5261-5271.

Chopra, A. K. \& Houston, C. W. (1999). Enterotoxins in Aeromonasassociated gastroenteritis. Microbes Infect 1, 1129-1137.

Chopra, A. K., Houston, C. W., Genaux, C. T., Dixon, J. D. \& Kurosky, A. (1986). Evidence for production of an enterotoxin and cholera toxin cross-reactive factor by Aeromonas hydrophila. J Clin Microbiol 24, 661664.

Chopra, A. K., Xu, X.-J., Ribardo, D., Gonzalez, M., Kuhl, K., Peterson, J. W. \& Houston, C. W. (2000). The cytotoxic enterotoxin of Aeromonas hydrophila induces proinflammatory cytokine production and activates arachidonic acid metabolism in macrophages. Infect Immun 68, 2808-2818.

Collee, J. G., Fraser, A. G., Marmion, B. P. \& Simmons, A. (editors) (1996). Mackie \& McCartney Practical Medical Microbiology, 14th edn. New York: Churchill Livingstone.

Cowan, S. T. (1979). Manual for the Identification of Medical Bacteria, 2nd edn. Edited by S. T. Cowan \& K. J. Steel. Cambridge: Cambridge University Press.

Cravioto, A., Gross, R. J., Scotland, S. M. \& Rowe, B. (1979). An adhesive factor in strains of Escherichia coli belonging to the traditional infantile enteropathogenic serotypes. Curr Microbiol 3, 95-99.

Cumberbatch, N., Gurwith, M. J., Langston, C., Sack, R. B. \& Brunton, J. L. (1979). Cytotoxic enterotoxin produced by Aeromonas hydrophila: relationship of toxigenic isolates to diarrheal disease. Infect Immun 23, 829-837.

Di Pietro, A., Picerno, I., Visalli, G., Chirico, C., Spataro, P., Cannavo, G. \& Scoglio, M. E. (2005). Aeromonas hydrophila exotoxin induces 
cytoplasmic vacuolation and cell death in VERO cells. New Microbiol 28, 251-259.

Edberg, S. C., Browne, F. A. \& Allen, M. J. (2007). Issues for microbial regulation: Aeromonas as a model. Crit Rev Microbiol 33, 89-100.

Ewing, W. H. \& Davis, B. R. (1981). Medium and tests for differentiation of Enterobacteriaceae. US Department of Health and Human Services publication no. CDC 81-8236. Washington, DC: US Department of Health and Human Services.

Goñi-Urriza, M., Capdepuy, M., Arpin, C., Raymond, N., Caumette, P. \& Quentin, C. (2000). Impact of an urban effluent on antibiotic resistance of riverine Enterobacteriaceae and Aeromonas spp. Appl Environ Microbiol 66, 125-132.

Hanninen, M. L. \& Siitonen, A. (1995). Distribution of Aeromonas phenospecies and genospecies among strains from water, foods or from clinical samples. Epidemiol Infect 115, 39-50.

Hanninen, M. L., Salmi, S., Mattila, L., Taipalinen, R. \& Siitonen, A. (1995). Association of Aeromonas spp. with travellers' diarrhoea in Finland. J Med Microbiol 42, 26-31.

Haque, Q. M., Sugiyama, A., Iwada, Y., Midorikawa, Y. \& Yamaguchi, T. (1996). Diarrheal and environmental isolates of Aeromonas spp. produce a toxin similar to Shiga-like toxin 1. Curr Microbiol 32, 239-245.

Henriques, I. S., Fonseca, F., Alves, A., Saavedra, M. J. \& Correia, A. (2006). Occurrence and diversity of integrons and beta-lactamase genes among ampicillin-resistant isolates from estuarine waters. Res Microbiol 157, 938-947.

Heuzenroeder, M. W., Wong, C. Y. F. \& Flower, R. L. P. (1999). Distribution of two hemolytic toxin genes in clinical and environmental isolates of Aeromonas spp.: correlation with virulence in a suckling mouse model. FEMS Microbiol Lett 174, 131-136.

Hiransuthikul, N., Tantisiriwat, W., Lertutsahakul, K., Vibhagool, A. \& Boonma, P. (2005). Skin and soft-tissue infections among tsunami survivors in southern Thailand. Clin Infect Dis 41, e93-e96.

Holt, G., Krieg, N. R., Sneath, P. H., Staley, J. T. \& Williams, S. T. (1994). Bergey's Manual of Determinative Bacteriology, 9th edn. Baltimore: Williams \& Wilkins.

Hughes, C., Phillips, R. \& Robert, A. P. (1982). Serum resistance among Escherichia coli strains causing urinary tract infection in relation to $\mathrm{O}$ type and the carriage of hemolysin, colicin, and antibiotic resistance determinants. Infect Immun 35, 270-275.

Janda, J. M. (1991). Recent advances in the study of the taxonomy, pathogenicity, and infectious syndromes associated with the genus Aeromonas. Clin Microbiol Rev 4, 397-410.

Janda, J. M. \& Abbott, S. L. (1998). Evolving concepts regarding the genus Aeromonas: an expanding panorama of species, disease presentations, and unanswered questions. Clin Infect Dis 27, 332-344.

Kaper, J., Seidler, R. J., Lockman, H. \& Colwell, R. R. (1979). Medium for the presumptive identification of Aeromonas hydrophila and Enterobacteriaceae. Appl Environ Microbiol 38, 1023-1026.

Kathuria, V. (2006). Controlling water pollution in developing and transition countries - lessons from three successful cases. J Environ Manage 78, 405-426.

Keasler, S. P. \& Hall, R. H. (1993). Detecting and biotyping Vibrio cholerae $\mathrm{O} 1$ with multiplex polymerase chain reaction. Lancet $\mathbf{3 4 1}$, 1661.

Khan, A., Yamasaki, S., Santo, T., Ramamurthy, T., Pal, A., Datta, S., Chowdhury, N. R., Das, S. C., Sikdar, A. \& other authors (2002). Prevalence and genetic profiling of virulence determinants of nonO157 Shiga toxin producing Escherichia coli isolated from cattle, beef and human cases in Calcutta, India. Emerg Infect Dis 8, 54-62.

Kingombe, C. I., Huys, G., Tonolla, M., Albert, M. J., Swings, J., Peduzzi, R. \& Jemmi, T. (1999). PCR detection, characterization, and distribution of virulence genes in Aeromonas spp. Appl Environ Microbiol 65, 5293-5302.

Ko, W. C., Yu, K. W., Liu, C. Y., Huang, C. T., Leu, H. S. \& Chuang, Y. C. (1996). Increasing antibiotic resistance in clinical isolates of Aeromonas strains in Taiwan. Antimicrob Agents Chemother 40, $1260-1262$.

Krovacek, K., Pasquale, V., Baloda, S. B., Soprano, V., Conte, M. \& Dumontet, S. (1994). Comparison of putative virulence factors in Aeromonas hydrophila strains isolated from the marine environment and human diarrheal cases in southern Italy. Appl Environ Microbiol 60, 1379-1382.

Kühn, I., Albert, M. J., Ansaruzzaman, M., Bhuiyan, N. A., Alabi, S. A., Huys, G., Islam, M. S., Janssen, P., Kersters, K. \& other authors (1997). Characterization of Aeromonas spp. isolated from humans with diarrhea, from healthy controls and from surface water in Bangladesh. J Clin Microbiol 35, 369-373.

Lawson, M. A., Burke, V. \& Chang, B. J. (1985). Invasion of HEp-2 cells by fecal isolates of Aeromonas hydrophila. Infect Immun 47, 680-683.

Ljungh, A., Popoff, M. \& Wadstrom, T. (1977). Aeromonas hydrophila in acute diarrheral disease; detection of enterotoxin and biotyping of strains. J Clin Microbiol 6, 96-100.

McKeon, D. M., Calabrese, J. P. \& Bissonnette, G. K. (1995). Antibiotic resistant Gram-negative bacteria in rural groundwater supplies. Water Res 29, 1902-1908.

Merino, S., Rubires, X., Aguilar, A., Alberti, S., Hernandez-Alles, S., Benedi, V. J. \& Tomas, J. M. (1996). Mesophilic Aeromonas sp. serogroup O:11 resistance to complement-mediated killing. Infect Immun 64, 5302-5309.

Merino, S., Aguilar, A., Nogueras, M. M., Regue, M., Swift, S. \& Tomas, J. M. (1999). Cloning, sequencing, and role of two phospholipases (A1 and C) from mesophilic Aeromonas sp. serogroup O:34. Infect Immun 67, 4008-4013.

Miranda, C. D. \& Castillo, G. (1998). Resistance to antibiotic and heavy metals of motile aeromonads from Chilean freshwater. Sci Total Environ 224, 167-176.

Nandi, B., Nandy, R. K., Mukhopadhyay, S., Nair, G. B., Shimada, T. \& Ghose, A. C. (2000). Rapid method for species-specific identification of Vibrio cholerae using primers targeted to the gene of outer membrane protein OmpW. J Clin Microbiol 38, 4145-4151.

Nataro, J. P., Sears, C., Fasano, A. \& Bloch, R. J. (2003). Enteric microbial toxins and the intestinal epithelial cytoskeleton. In Microbial Pathogenesis and the Intestinal Epithelial Cell, pp. 301332. Edited by G. A. Hecht. Washington, DC: American Society for Microbiology.

NCCLS (2002). Performance Standards for Antimicrobial Susceptibility Testing. 12th informational supplement, NCCLS document M100-S12. Wayne, PA: National Committee for Clinical Laboratory Standards.

Parsot, C., Taxman, E. \& Mekalanos, J. J. (1991). ToxR regulates the production of lipoproteins and the expression of serum resistance in Vibrio cholerae. Proc Natl Acad Sci U S A 88, 1641-1645.

Pollard, D. R., Johnson, W. M., Lior, H., Tyler, S. D. \& Rozee, K. R. (1990). Detection of the aerolysin gene in Aeromonas hydrophila by the polymerase chain reaction. J Clin Microbiol 28, 2477-2481.

Presley, S. M., Rainwater, T. R., Austin, G. P., Platt, S. G., Zak, J. C., Cobb, G. P., Marsland, E. J., Tian, K., Zhang, B. \& other authors (2006). Assessment of pathogens and toxicants in New Orleans, LA following Hurricane Katrina. Environ Sci Technol 40, 468-474.

Rahman, M., Huys, G., Kühn, I., Rahman, M. \& Möllby, R. (2009). Prevalence and transmission of antimicrobial resistance among Aeromonas populations from a duckweed aquaculture based hospital sewage water recycling system in Bangladesh. Antonie Van Leeuwenhoek 96, 313-321. 
Ramamurthy, T., Bag, P. K., Pal, A., Bhattacharya, S. K. Bhattacharya, M. K., Sen, D., Shimada, T., Takeda, T. \& Nair, G. B. (1993). Virulence patterns of $V$. cholerae Non-O1 isolated from hospitalized patients with acute diarrhoea in Calcutta, India. J Med Microbiol 39, 310-317.

Richardson, S. H., Giles, J. C. \& Kruger, K. S. (1984). Sealed adult mice: new model for enterotoxin evaluation. Infect Immun 43, 482-486.

Rippey, S. R. \& Cabelli, V. J. (1979). Membrane filter procedure for enumeration of Aeromonas hydrophila in fresh water. Appl Environ Microbiol 38, 108-113.

Schneider, D. R. \& Parker, C. D. (1978). Isolation and characterization of protease-deficient mutants of Vibrio cholerae. J Infect Dis 138, 143-151.

Seidler, R. J., Allen, D. A., Colwell, R. R., Joseph, S. W. \& Daily, O. P. (1980). Biochemical characteristics and virulence of environmental group F bacteria isolated in the United States. Appl Environ Microbiol 40, 715-720.

Sha, J., Kozlova, E. V. \& Chopra, A. K. (2002). Role of various enterotoxins in Aeromonas hydrophila-induced gastroenteritis: generation of enterotoxin gene-deficient mutants and evaluation of their enterotoxic activity. Infect Immun 70, 1924-1935.
Sinha, S., Shimada, T., Ramamurthy, T., Bhattacharya, S. K., Yamasaki, S., Takida, Y. \& Nair, G. B. (2004). Prevalence, serotype distribution, antibiotic susceptibility and genetic profiles of mesophilic Aeromonas species isolated from hospitalized diarrhoeal cases in Kolkata, India. J Med Microbiol 53, 527-534.

Smith, H. L., Jr (1970). A presumptive test for vibrios: the 'string' test. Bull World Health Organ 42, 817-818.

Suarez, G., Sierra, J. C., Sha, J., Wang, S., Erova, T. E., Fadl, A. A., Foltz, S. M., Horneman, A. J. \& Chopra, A. K. (2008). Molecular characterization of a functional type VI secretion system from a clinical isolate of Aeromonas hydrophila. Microb Pathog 44, 344-361.

Wang, G., Tyler, K. D., Munro, C. K. \& Johnson, W. M. (1996). Characterization of cytotoxic, hemolytic Aeromonas caviae clinical isolates and their identification by determining presence of a unique hemolysin gene. J Clin Microbiol 34, 3203-3205.

West, P. A. \& Colwell, R. R. (1984). Identification and characterization of Vibrionaceae. An overview. In Vibrios in the Environment, pp. 285363. Edited by R. Colwell. New York: Wiley.

Yamada, S., Matsushita, S., Dejsirilet, S. \& Kudoh, Y. (1997). Incidence and clinical symptoms of Aeromonas-associated traveller's diarrhoea in Tokyo. Epidemiol Infect 119, 121-126. 